\title{
The outcome of hepatitis B virus infection in pregnancy
}

\author{
Y. E. CoSSART \\ M.B., M.R.C.Path. \\ Virus Reference Laboratory, Central Public Health Laboratory, Colindale
}

\section{Summary}

The literature concerning hepatitis $B$ in pregnancy is reviewed and problems of management of both the acute and chronic infections are discussed.

Clinical hepatitis occurs only about once in 20000 pregnancies in Western Europe and North America (Sever and White, 1968) but it seems to be much more common in pregnant women in areas such as the Middle East (Zondek and Bromberg, 1947) and Africa where hepatitis is hyperendemic in the general population. In both high- and low-incidence areas the frequency and severity of the illness increase greatly during the last trimester (Table 1) and in many countries hepatitis is a significant cause of maternal mortality. As premature lakour often accompanies the onset of jaundice the perinatal mortality is also high (Table 2).

TABLE 1. Hepatitis at different states of pregnancy

\begin{tabular}{|c|c|c|c|}
\hline \multirow[b]{2}{*}{ Country } & \multicolumn{3}{|c|}{ No. of cases ( $\%$ mortality) } \\
\hline & $\begin{array}{l}\text { 1st } \\
\text { trimester }\end{array}$ & $\begin{array}{l}\text { 2nd } \\
\text { trimester }\end{array}$ & $\begin{array}{c}\text { 3rd } \\
\text { trimester }\end{array}$ \\
\hline $\begin{array}{l}\text { Iran (Borhanmanesh } \\
\text { et al., 1973) }\end{array}$ & $6(16)$ & 17 (17) & 59 (33) \\
\hline $\begin{array}{l}\text { India (Malkani and } \\
\text { Grewel, 1957) }\end{array}$ & $8(38)$ & $55(20)$ & $81(59)$ \\
\hline $\begin{array}{l}\text { USA (Siegel et al., } \\
\text { 1966) }\end{array}$ & $4(0)$ & 7 (14) & $22(0)$ \\
\hline $\begin{array}{l}\text { Israel (Zondek and } \\
\text { Bromberg, 1947) }\end{array}$ & & $6(0)$ & $15(34)$ \\
\hline $\begin{array}{l}\text { Denmark (Hammerli, } \\
\text { 1966) }\end{array}$ & & $3(0)$ & $85(1)$ \\
\hline $\begin{array}{l}\text { Australia (Bennett } \\
\text { et al., 1967) }\end{array}$ & & $19(0)$ & $109(0)$ \\
\hline
\end{tabular}

On the other hand, a prospective study of viral infection in pregnancy (Siegel, Fuerst and Peress, 1966) has shown that there is no increase in fetal loss or congenital abnormality following hepatitis in the first half of pregnancy. The suggestion (Stoller and Collmann, 1965) that maternal hepatitis occurring near the time of conception is associated with an increased incidence of Down's syndrome has not
TABLE 2. Perinatal mortality of infants born to mothe with acute hepatitis

\begin{tabular}{|c|c|c|c|}
\hline Country & & No. of babies & $\begin{array}{l}\text { Percent } c \\
\text { mortality }\end{array}$ \\
\hline $\begin{array}{l}\text { India (Malkani and } \\
\text { Grewel, 1957) }\end{array}$ & $\begin{array}{l}34 \\
78\end{array}$ & $\begin{array}{l}\text { (full term) } \\
\text { (premature) }\end{array}$ & $\begin{array}{l}18 \\
52\end{array}$ \\
\hline $\begin{array}{l}\text { Israel (Zondek and } \\
\text { Bromberg, 1947) }\end{array}$ & $\begin{array}{r}22 \\
5\end{array}$ & $\begin{array}{l}\text { (full term) } \\
\text { (premature) }\end{array}$ & $\begin{array}{r}0 \\
80\end{array}$ \\
\hline $\begin{array}{l}\text { Iran (Borhanmanesh } \\
\text { et al., 1973) }\end{array}$ & $\begin{array}{l}32 \\
29\end{array}$ & $\begin{array}{l}\text { (mother's illness } \\
\text { mild) } \\
\text { (mother's illness } \\
\text { severe) }\end{array}$ & $\begin{array}{l}22 \\
66\end{array}$ \\
\hline Ghana (Mansell, 1955) & 15 & (all cases) & 60 \\
\hline $\begin{array}{l}\text { U.S.A. (Siegel et al., } \\
\text { 1966) }\end{array}$ & 65 & (all cases) & 8రి \\
\hline $\begin{array}{l}\text { U.S.A. (Adams and } \\
\text { Combs, 1965) }\end{array}$ & 28 & (all cases) & 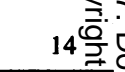 \\
\hline
\end{tabular}

been substantiated by later studies (Dietzman et al 1972).

Ever since Stokes et al. (1954) described a famil where two children developed neonatal hepatitis an showed that their mother was a persistent carrier, if has been widely believed that hepatitis B may be af important cause of 'congenital' liver disease. Withi the advent of hepatitis $B$ surface antigen $\left(\mathrm{HB}_{\mathrm{s}} \mathrm{Ag}\right.$ tests it has become possible to assess the situatio further. In England about $20 \%$ of pregnant patient with hepatitis are $\mathrm{HB}_{\mathrm{s}} \mathrm{Ag}$-positive (Cossart and Cohen, 1976); this is a similar proportion to that found amongst other young adults with hepatitis. IB the Middle East, however, Christie et al. (1976) have reported that very few pregnant hepatitis patients are $\mathrm{HB}_{\mathrm{s}} \mathrm{Ag}$ positive. It is likely that there are great differences between countries in this respect.

The infants born after pregnancies complicated by jaundice seldom suffer from clinically obvious liven disease (Hsia, Taylor and Gellis, 1952; Adams ang Combs, 1965) but when the offspring of the mother's who had hepatitis $B$ are tested, many are $\mathbf{H B}_{\mathrm{s}} \mathrm{Ag}$ positive and some have biochemical and histologicap evidence of liver disease (Gillespie et al., 1970: Wright et al., 1970; Turner et al., 1971; Marsha $\mathbb{B}^{\circ}$ and Dudgeon, 1972). 
The proportion of infected infants is low when the cases of maternal hepatitis occur during the first half of pregnancy, but it rises to about $50 \%$ when the onset is within 4 weeks before or after delivery (Table 3).

TABLE 3. Risk of infection in infants whose mothers develop acute hepatitis within 4 weeks before or after delivery

\begin{tabular}{llccc}
\hline Reference & Country & $\begin{array}{c}\text { No. of } \\
\text { infants }\end{array}$ & $\begin{array}{c}\text { No. cord } \\
\text { blood } \\
\text { HEs }\end{array}$ & $\begin{array}{c}\text { No. } \\
\text { follow-up }\end{array}$ \\
\hline $\begin{array}{l}\text { HBs } \mathbf{A g}+ \\
\text { Holzbach (1972) }\end{array}$ & U.S.A. & 2 & 0 & 0 \\
$\begin{array}{l}\text { Schweitzer } \\
\text { et } \text { al. }(1973)\end{array}$ & U.S.A. & 19 & 2 & 13 \\
$\begin{array}{l}\text { Merrill } \text { et al. } \\
(1972)\end{array}$ & U.S.A. & 5 & 1 & 4 \\
$\begin{array}{l}\text { Cossart and } \\
\text { Cohen }(1976)\end{array}$ & England & 6 & 0 & 3 \\
\hline
\end{tabular}

The situation regarding hepatitis B carrier mothers is much less clear (Schweitzer et al., 1973). It can be seen from Table 4 that carriers in Denmark and Greece seldom transmit to their infants while those in Taiwan often do. The reason for this difference and the mechanism of transmission are poorly understood.

TABLE 4. Risk of infections in infants whose mothers are hepatitis B-carriers

\begin{tabular}{llccc}
\hline Reference & Country & $\begin{array}{c}\text { No. of } \\
\text { infants }\end{array}$ & $\begin{array}{c}\text { No. cord } \\
\text { blood } \\
\text { HBsAgt }\end{array}$ & $\begin{array}{c}\text { No. } \\
\text { follow-up }\end{array}$ \\
\hline HBs Ag+
\end{tabular}

Many infants born to $\mathrm{HB}_{\mathrm{s}} \mathrm{Ag}$-positive mothers do not have detectable antigen in their cord blood (Smithwick and Go, 1970; Skinhøj et al., 1972), but some of these $\mathbf{H B}_{\mathrm{S}} \mathrm{Ag}$-negative infants subsequently develop antigenaemia (Table 3). Conversely infants with $\mathrm{HB}_{\mathrm{s}} \mathrm{Ag}$-positive cord blood may rapidly become negative. Although they have clearly been exposed, some of these infants produce no subsequent evidence of infection.

The age at which infected infants become $\mathrm{HB}_{\mathrm{s}} \mathrm{Ag}$ positive varies, but it is usually before the sixth week of life (Merrill, Dubois and Kohler, 1972; Schweitzer et al., 1973; Hitchins, Gostling and O'Driscoll,
1974). This suggests that transmission occurs during the last few weeks of gestation if an average incubation period of 90 days is expected. However, the chance of avoiding contact with maternal blood during delivery is so remote that it is possible that all infants are exposed at that time and that some failure of the mother's infection governs the outcome in the infant.

The titre of the maternal antigen correlated well with the likelihood of transmission in Taiwan (Stevens et al., 1975) but not in England (Cossart and Cohen, 1976). In any event the correlation could well be indirect since the titres found in acute hepatitis patients are usually higher than those in asymptomatic carriers.

The subtype of the antigen is also unlikely to explain the difference between individuals since the prevailing subtype is ad amongst the 'non-transmitting' carriers in Denmark and England but ay in Greece, while the 'transmitting' carriers in the Far East have the ad subtype. Not enough is known about the minor determinants in this context, but they may reflect important strain differences amongst hepatitis B viruses.

So far, the most important factor recognizable in determining transmission from mother to infant is the activity of the mother's liver disease, but this is difficult to assess during pregnancy because of the physiological alterations in liver function. Many 'healthy' carriers have chronic hepatitis which is only revealed by specific investigation and in at least one larger series from the U.S.A. (Schweitzer, Edwards and Brezina, 1975) where 'carriers' were reported to have transmitted hepatitis to their infants it is clear that the authors' definition included mothers with chronic hepatitis following an acute attack of 'hippie hepatitis'. It is still too early to know whether the $e$ antigen will be a reliable indicator of the risk of transmission and in particular serve to identify those exceptional carriers who are at risk of producing severely affected infants in subsequent pregnancies (Kohler et al., 1974).

Very little is known about the outlook for infants who acquire hepatitis $B$ in the first few months of life. The first reports showed that severe (Wright et al., 1970; Marshall and Dudgeon 1972; McCarthy, 1973) and even fatal (Fawaz et al., 1975; Kohler et al., 1974) liver disease could occur but as more cases have been studied it has become obvious that long term, asymptomatic carriage is the more usual result. This is to be expected in view of the immaturity of the immune response at this age, but it is not yet known how many of the infants are able to clear the antigen as they get older (Dahlquist and Nordenfelt, 1974).

Those who remain persistent carriers may suffer from chronic liver disease in later life. Familial 
TABLE 5. Hepatitis in pregnancy-summary of treatment

\begin{tabular}{|c|}
\hline HBsAg-Positive $_{\text {S }}$ \\
\hline $\begin{array}{l}\text { (1) Acute hepatitis } \\
\text { Before } 28 \text { th week-No action (no risk congenital defect) }\end{array}$ \\
\hline $\begin{array}{l}\text { After } 28 \text { th week-Conservative treatment (risk premature labour). } \\
\text { If mother still } \mathrm{HB}_{\mathrm{s}} \mathrm{Ag}+\text { at delivery treat as below. }\end{array}$ \\
\hline $\begin{array}{l}+4 \text { weeks delivery- } 50 \% \text { risk of infecting infant. Test cord blood. } \\
\text { If negative, give infant } 500 \mathrm{mg} \text { specific hepatitis B immunoglobulin } \\
\text { immediately and if infant still } \mathrm{HB}_{\mathrm{s}} \mathrm{Ag} \text {-negative repeat in } 6 \text { weeks. } \\
\text { Follow-up infant for } 1 \text { year. If cord blood } \mathrm{HB} \text { s } \mathrm{Ag} \text {-positive retest } \\
\text { infant in } 48 \mathrm{~h} \text {. If negative or only } \mathrm{HB}_{\mathrm{s}} \mathrm{Ag} \text {-positive by } \mathrm{HA} \text { and RIA, } \\
\text { give specific immunoglobulin. If strongly positive, follow-up until } \\
\text { negative. No need to separate mother and infant or to stop breast } \\
\text { feeding if established. }\end{array}$ \\
\hline
\end{tabular}

(2) Contact hepatitis

Inoculation injury-Treat as if not pregnant.

Household contact-No action unless contact husband has acute hepatitis when give specific immunoglobulin $(500 \mathrm{mg})$ if wife is HBsAg-negative.

More remote contact-No action.

(3) Chronic hepatitis

Treat infant as if mother had acute hepatitis at term.

(4) Hepatitis carrier

No action. Follow infant for 1 year.

(5) Previous infant neonatal hepatitis

If mother $\mathrm{HB}_{\mathbf{s}} \mathrm{Ag}$-positive treat infant with specific immunoglobulin as above.
No action (no risk congenital defect).

Conservative treatment (risk premature labour).

? Little risk clinical illness in infant. No need to separate mother and infant or to stop breast feeding if mother well enough. No contraindication to giving infant $250 \mathrm{mg}$ normal immunoglobulin but probably unnecessary.

Treat as if not pregnant.

$500 \mathrm{mg}$ normal immunoglobulin.

No action.

No action (? no risk transmission to infant).

Look for non-infective causes. clustering of hepatitis B infections is well recognized in some communities (Ohbayashi, Okochi and Majumi, 1972; Mazzur, Blumberg and Frielaender, 1974) and circumstantial evidence suggests that a carrier mother is often the source of infection. However, transplacental transmission does not occur often enough to account for the number of adult carriers in Western Europe or North America. It may well be the major factor in other countries such as Taiwan (Stevens et al., 1975) while in yet other areas children who are chronic carriers frequently present with non-hepatic manifestations of 'immune complex disease' such as glomerulonephritis (Brozosko et al., 1974). The factors responsible for these differences in response are unknown.

The management of individual patients presents problems which are summarized in Table 5. The infant born to a mother with acute hepatitis B near term is clearly at risk of infection and the administration of specific hepatitis B immunoglobulin to these infants should be considered. Half the adult dose has been used (Fawaz et al., 1975; Kohler et al., 1974; Cossart and Cohen, 1976) but its efficacy in these circumstances is unproved. It is often convenient to separate mother and infant until the mother's hepatitis subsides, but post-natal exposure by personal contact or because the milk contains
$\mathrm{HB}_{\mathrm{s}} \mathrm{Ag}$ (Boxall, 1975) is likely to be trivial compareds with that during delivery.

The mother with acute hepatitis is better isolatedö since it will seldom te known whether she has@ hepatitis A or B when she is admitted. Carriers in $\vec{F}$ England seldom transmit to their infants so a3 policy of non-intervention seems best for the group. Routine screening of pregnant women for $\mathbf{H B}_{\mathrm{s}} \mathbf{A} \mathbf{g}$. cannot be justified as a preventive measure, ando separation of mother and infant is misguided when it is unlikely that the mother will become $\mathrm{HB}_{\mathrm{s}} \mathrm{Ag}-\overline{\mathrm{O}}$ negative within a foreseeable time. There is noevidence that breast feeding is a significant factor ino transmitting hepatitis B to the infants of carriers (Beasley et al., 1975) and its prohibition is probably? unnecessary.

The actual delivery of $\mathrm{HB}_{\mathrm{s}} \mathrm{Ag}$-positive patients may present hazards to the staff. The main risk is from accidental inoculation with a blood-stained needle and the general hospital policy should include arrangements for the routine reporting of all such $N$ incidents so that specific immunoglobulin can be offered whenever it is warranted.

Apart from this, the main problem is the laundry and it is certainly advisable to send all the patient's? bed linen to the hospital 'soiled wash'. It is conve- 0 nient for the nursing staff if a single room is available? 
so that the infant can remain 'rooming in' with the mother. After they go home the room should be cleaned with a dilute chlorine-based disinfectant but more rigorous measures are unnecessary.

In this context it is important to remember that every maternity ward will deal with far more unrecognized carriers than those identified by a chance $\mathrm{HB}_{3} \mathrm{Ag}$ test. If the general routine is satisfactory there will be no need to provide specific facilities for known carriers.

\section{References}

ADAMS, R.H. \& Combs, B. (1965) Virus hepatitis during pregnancy. Journal of the American Medical Association. 192, 195.

Aziz, M.A., Khan, G., Khanum, T. \& Siddiqi, A-R. (1973) Transplacental and postnatal transmission of the hepatitis associated antigen. Journal of Infectious Diseases, 127, 110.

BenNett, N. McK., Forbes, J.A., Lucas, C.R. \& Kugers, A. (1967) Infective hepatitis and pregnancy: analysis of liver function test results. Medical Journal of Australia, 2, 974.

Beasley, R.P., Stevens, C.E., Shiao, I. \& Mung, H.-C. (1975) Evidence against breast feeding as a mechanism for vertical transmission of hepatitis B. Lancet, ii, 740.

Borhanmanesh, F., Haghighi, P., Hekmat, K., Rezaizadeh, K. \& Ghavami, A.G. (1973) Viral hepatitis during pregnancy: severity and effect on gestation. Gastroenterology, 64, 304.

BoXALL, E.H. (1975) Breast feeding and hepatitis B. Lancet, ii, 979.

Brozosko, W.J., Kraweynski, K., Nazarewicz, T., MORZYNOHKa, M. \& NowoslaWsKI, A. (1974) Glomerulonephritis associated with hepatitis $B$ surface antigen immune complexes in children. Lancet, ii, 477.

Christie, A.B., Allam, A.A., Aref, M.K., Elmuntasser, I.H. \& EL NageH, M. (1976) Pregnancy hepatitis in Libya. Lancet, ii, 827.

Cossart, Y.E. \& CoHEN, B.J. (1976) Transmission of hepatitis to fetus and infant. In: Liver Diseases in Infancy and Childhood: Proceedings of a Conference, Paris, June 1976 (edited by S. R. BerenberG). Martinus Nijhoff, The Hague, p. 180.

Dahlquist, E. \& Nordenfelt, E. (1974) Neonatal hepatitis type B: a three-year follow-up. Scandinavian Journal of Infectious Diseases, 6, 305.

Dietzman, D.E., Madden, D.L., Sever, J.L., LANDer, J.J. \& Purcell, R.H. (1972) Lack of relationship between Down's syndrome and maternal exposure to Australia antigen. American Journal of Diseases of Children, 124, 195.

Fawaz, K.A., Grady, G.F., Kaplan, M.M. \& Gellis, S.S. (1975) Repetitive maternal-fetal transmission of fatal hepatitis B. New England Journal of Medicine, 293, 1357.

Gillespie, A., Dorman, D., Walker-Smith, J.A. \& YU, J.S. (1970) Neonatal hepatitis and Australia antigen. Lancet, ii, 1081.

HAMMERLI, U.P. (1966) Jaundice during pregnancy with special emphasis on recurrent jaundice during pregnancy and its differential diagnosis. Acta medica scandinavica, 179, Suppl. 444, 23.

Hitchins, A.J., Gostling, J.V.T. \& O'Driscoll, W.B. (1974) Serum hepatitis in late pregnancy. Lancet, ii, 343.

Holzbach, R.T. (1972) Australia antigen hepatitis in pregnancy-evidence against transplacental transmission of Australia antigen in early and late pregnancy. Archives of Internal Medicine, 130, 234.

Hsia, J.D., TAYLOR, R.G. \& Gellis, S.S. (1952) A long term follow-up study on infectious hepatitis during pregnancy. Journal of Pediatrics, 41, 13.
Kohler, P.F., Dubois, R.S., Merrill, D.A. \& Bowes, W.A. (1974) Prevention of chronic neonatal hepatitis B virus infection with antibody to the hepatitis B surface antigen. New England Journal of Medicine, 291, 1378.

McCarthy, J.W. (1973) Hepatitis B antigen (HB Ag)positive chronic aggressive hepatitis and cirrhosis in an 8-month-old infant: a case report. Journal of Pediatrics, 83, 638 .

Malkani, P.K. \& Grewel, A.K. (1957) Observation on infectious hepatitis in pregnancy. Indian Journal of Medical Research, 45, Suppl., 77.

Mansell, R.V. (1955) Infectious hepatitis in the first trimester of pregnancy and its effect on the fetus. American Journal of Obstetrics and Gynecology, 69, 1136.

Marshall, W.C. \& Dudgeon, J.A. (1972) Australia antigen in a child with congenital malformation and in his mother. American Journal of Diseases of Children, 123, 378.

Mazzur, S., Blumberg, B.S. \& Frielaender, J.S. (1974) Silent maternal transmission of Australia antigen. Nature. London, 247, 41.

Merrill, D.A., Dubois, R.S. \& Kohler, P.F. (1972) Neonatal onset of the hepatitis-associated-antigen carrier state. New England Journal of Medicine, 287, 1280.

Ohbayashi, A., OKochi, K. \& Mayumi, M. (1972) Familial clustering of carriers of Australia antigen and patients with chronic liver disease or primary liver cancer. Gastroenterology, 62, 618.

Papaevangelou, G., Hoofnagle, J. \& Kremastinou, J. (1974) Transplacental transmission of hepatitis B virus by symptom-free chronic carrier mothers. Lancet, ii, 746.

Schweitzer, I.L., Edwards, V.M. \& Brezina, M. (1975) e Antigen in $\mathrm{Hb}_{\mathrm{s}} \mathrm{Ag}$ carrier mothers. New England Journal of Medicine, 293, 940.

Schweitzer, I.L., Mosley, J.W., Ashcavi, M., Edwards, V.M. \& Overby, L.B. (1973) Factors influencing neonatal infection by hepatitis B. Gastroenterology, 65, 277.

Sever, J. \& White, L.R. (1968) Intrauterine viral infection. American Journal of Respiratory Diseases, 19, 471.

Siegel, M., Fuerst, H.T. \& Peress, N.S. (1966) Comparative fetal mortality in maternal virus diseases. A prospective study of rubella, measles, mumps, chicken pox and hepatitis. New England Journal of Medicine, 274, 768-771.

Skinhøj, P., Olesen, H., Cohn, J. \& Mikkelsen, M. (1972) Hepatitis-associated antigen in pregnant women. Acta pathologica et microbiologica scandinavica, 80, 362.

Smithwick, E.M. \& Go, S.C. (1970) Hepatitis associated antigen in cord and maternal sera. Lancet, ii, 1080.

Stevens, C.E., Beasley, R.P., Tsui, J. \& Lee, W-C. (1975) Vertical transmission of hepatitis $B$ antigen in Taiwan. New England Journal of Medicine, 292, 771.

Stokes, J., Berk, J.E., Malamut, L.L., Drake, M.E., Barondess, J.A., BASHE, W.J., WOLMAN, I.J., FARQUhaR, J.D., Bevan, B., Drummond, R.J., Maycock, W. D'A., CAPPS, R.B. \& BENNETT, A.M. (1954) The carrier state in viral hepatitis. Journal of the American Medical Association, 15, 1059.

Stoller, A. \& CollmanN, R.D. (1965) Incidence of infectious hepatitis followed by Down's syndrome nine months later. Lancet, ii, 1221.

Turner, G.C., Field, A.M., LASheen, R.M., Todd, R.McL., White, G.B.B. \& Porter, A.A. (1971) SH (Australia) antigen in early life. Archives of Diseases in Childhood, 46, 616.

Wright, R., Perkins, J.R., Bower, B.D. \& Jerrome, A.W. (1970) Cirrhosis associated with the Australia antigen in an infant who acquired hepatitis from her mother. British Medical Journal, 4, 719.

ZONDEK, B. \& BROMBERG, Y.M. (1947) Infectious hepatitis in pregnancy. Journal of the Mount Sinai Hospital, 14, 232. 